\title{
ENGINEERING DEVELOPMENT OF COAL-FIRED HIGH-PERFORMANCE POWER SYSTEMS
}

\author{
DE-AC22-95PC95143
}

TECHNICAL PROGRESS REPORT NO. 21 JULY THROUGH SEPTEMBER 2000

\author{
Prepared for \\ Department of Energy \\ Federal Energy Technology Center \\ Pittsburgh, Pennsylvania
}

DECEMBER 2000 
"This report was prepared as an account of work sponsored by an agency of the United States Government. Neither the United States Government nor any agency thereof, nor any of their employees, makes any warranty, express or implied, or assumes any legal liability or responsibility for the accuracy, completeness, or usefulness of any information, apparatus, product, or process disclosed, or represents that its use would not infringe privately owned rights. Reference herein to any specific commercial product, process, or service by trade name, trademark, manufacturer, or otherwise does not necessarily constitute or imply its endorsement, recommendation, or favoring by the United States Government or any agency thereof. The views and opinions of authors expressed herein do not necessarily state or reflect those of the United States Government or any agency thereof." 


\section{ABSTRACT}

A High Performance Power System (HIPPS) is being developed. This system is a coal-fired, combined cycle plant with indirect heating of gas turbine air. Foster Wheeler Development Corporation and a team consisting of Foster Wheeler Energy Corporation, Bechtel Corporation, University of Tennessee Space Institute and Westinghouse Electric Corporation are developing this system. In Phase 1 of the project, a conceptual design of a commercial plant was developed. Technical and economic analyses indicated that the plant would meet the goals of the project which include a 47 percent efficiency (HHV) and a 10 percent lower cost of electricity than an equivalent size PC plant.

The concept uses a pyrolysis process to convert coal into fuel gas and char. The char is fired in a High Temperature Advanced Furnace (HITAF). The HITAF is a pulverized fuel-fired boiler/air heater where steam is generated and gas turbine air is indirectly heated. The fuel gas generated in the pyrolyzer is then used to heat the gas turbine air further before it enters the gas turbine.

The project is currently in Phase 2 which includes engineering analysis, laboratory testing and pilot plant testing. Research and development is being done on the HIPPS systems that are not commercial or being developed on other projects. Pilot plant testing of the pyrolyzer subsystem and the char combustion subsystem are being done separately.

This report addresses the areas of technical progress for this quarter. The existing bubbling bed plant in Livingston, New Jersey is to be modified to a circulating fluidized bed (CFB) pyrolyzer. The detailed design of the major process equipment to be installed at the pilot plant is completed and reported in the earlier quarter report. During this quarter, one modification was made to the original CFB pyrolyzer design. In the original design, J-valve was used to be the pressure seal device between the pyrolyzer reactor and solids return loop. Based on FW successful experience with the biomass gasification, Jvalve is replaced with a simple angled solids-return leg. This angled solids-return leg does not require any bottom fluidization with either nitrogen or steam. As a result, the pyrolyzer operation is further simplified. The angled solids-return leg is easy to construct.

The demolition of the existing bubbling bed pyrolyzer is complete. The procurement work of the new addition and modification to the new CFB pyrolyzer is underway in this quarter. In order to prepare the CETF for the HIPPS char combustion test program, the construction work of a new indirect char feeding system to be used for the wall-fired char combustion tests was completed during the last quarter. The commission of the new indirect feed system was performed in this quarter. 


\section{TABLE OF CONTENTS}

PAGE

NO.

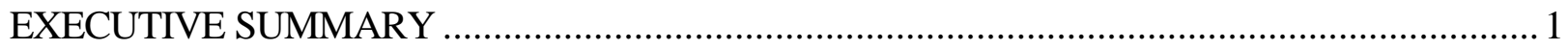

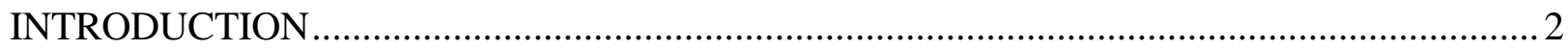

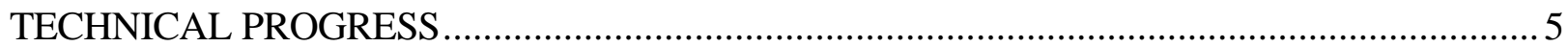

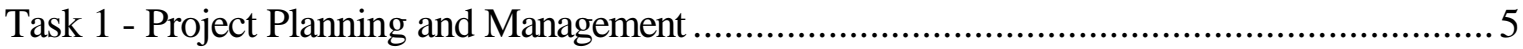

Task 2 - Engineering Research and Development ...................................................... 5

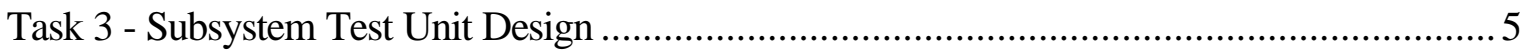

Subtask 3.1 - Livingston Pilot Plant Design......................................................... 5

Subtask 3.2 - Char Combustion System Test Design............................................. 6

Task 4 - Subsystem Test Unit Construction .............................................................. 6

Subtask 4.1 - Livingston Pilot Plant Construction........................................................ 6

Subtask 4.2 - Char Combustion System Construction ............................................... 6

Task 5 - Subsystem Test Unit Testing .................................................................. 6 


\section{$\underline{\text { LIST OF FIGURES \& TABLES }}$}

FIGURE

PAGE

NO.

NO.

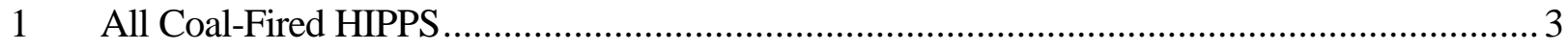

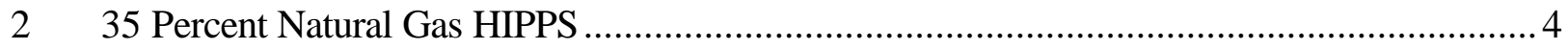

3 Simplified HIPPS Repowering Process Flow Diagram .................................................... 4

4 CFB Pyrolyzer General Arrangement for Test Series I ................................................ 7

5 CFB Pyrolyzer General Arrangement for Test Series II ............................................ 8

6 CFB Pyrolyzer With A J-Valve As the Pressure Seal Device ........................................... 9

7 CFB Pyrolyzer With An Angled Solids-Return Leg As the Pressure Seal Device .................. 10

8 Overall CFB Pyrolyzer System Construction and Testing Schedule.................................... 11 


\section{EXECUTIVE SUMMARY}

The High Performance Power System is a coal-fired, combined cycle power generating system that will have an efficiency of greater than 47 percent (HHV) with NOx and SOx less than $0.025 \mathrm{Kg} / \mathrm{GJ}(0.06$ $\mathrm{lb} / \mathrm{MMBtu}$ ). This performance is achieved by combining a coal pyrolysis process with a High Temperature Advanced Furnace (HITAF). The pyrolysis process consists of a pressurized fluidized bed reactor which is operated at about $926^{\circ} \mathrm{C}\left(1700^{\circ} \mathrm{F}\right)$ at substoichiometric conditions. This process converts the coal into a low-Btu fuel gas and char. These products are then separated.

The char is fired in the HITAF where heat is transferred to the gas turbine compressed air and to the steam cycle. The HITAF is fired at atmospheric pressure with pulverized fuel burners. The combustion air is from the gas turbine exhaust stream. The fuel gas from the pyrolysis process is fired in a Multi-Annular Swirl Burner (MASB) where it further heats the gas turbine air leaving the HITAF. This type of system results in very high efficiency with coal as the only fuel.

We are currently in Phase 2 of the project. In Phase 1, a conceptual plant design was developed and analyzed both technically and economically. The design was found to meet the project goals. The purpose of the Phase 2 work is to develop the information needed to design a prototype/commercial plant. Phase 3 of the overall HIPPS contract has been deleted. In addition to engineering analysis and laboratory testing, the subsystems that are not commercial or being developed on other projects will be tested at pilot plant scale. The FWDC Second-Generation PFB pilot plant in Livingston, NJ, has been modified to test the pyrolyzer subsystem. The FWDC Combustion and Environmental Test Facility (CETF) in Dansville, NY, has been modified to test the char combustion system.

This report addresses the areas of technical progress for this quarter. The existing bubbling bed plant in Livingston, New Jersey is to be modified to a circulating fluidized bed (CFB) pyrolyzer. The detailed design of the major process equipment to be installed at the pilot plant is completed and reported in the earlier quarter report. During this quarter, one modification was made to the original CFB pyrolyzer design. In the original design, J-valve was used to be the pressure seal device between the pyrolyzer reactor and solids return loop. Based on FW successful experience with the biomass gasification, J-valve is replaced with a simple angled solids-return leg. This angled solids-return leg does not require any bottom fluidization with either nitrogen or steam. As a result, the pyrolyzer operation is further simplified. The angled solids-return leg is easy to construct.

The demolition of the existing bubbling bed pyrolyzer is complete. The procurement work of the new addition and modification to the new CFB pyrolyzer is underway in this quarter. In order to prepare the CETF for the HIPPS char combustion test program, the construction work of a new indirect char feeding system to be used for the wall-fired char combustion tests was completed during the last quarter. The commission of the new indirect feed system was performed in this quarter. 


\section{INTRODUCTION}

In Phase 1 of the project, a conceptual design of a coal-fired high performance power system was developed, and small scale R\&D was done in critical areas of the design. The current Phase of the project includes development through the pilot plant stage.

Foster Wheeler Development Corporation (FWDC) is leading a team of companies in this effort. These companies are:

- Foster Wheeler Energy Corporation (FWEC)

- Bechtel Corporation

- Westinghouse Electric Corporation

The power generating system being developed in this project will be an improvement over current coal-fired systems. Goals have been identified that relate to the efficiency, emissions, costs and general operation of the system. These goals are:

- Total station efficiency of at least 47 percent on a higher heating value basis.

- Emissions:

$$
\begin{aligned}
& \text { NOx }<0.06 \mathrm{lb} / \mathrm{MMBtu} \\
& \mathrm{SOx}<0.06 \mathrm{lb} / \mathrm{MMBtu} \\
& \text { Particulates }<0.003 \mathrm{lb} / \mathrm{MMBtu}
\end{aligned}
$$

- All solid wastes must be benign with regard to disposal.

- Over 95 percent of the total heat input is ultimately from coal, with initial systems capable of using coal for at least 65 percent of the heat input.

The base case arrangement of the HIPPS cycle is shown in Figure 1. It is a combined cycle plant. This arrangement is referred to as the All Coal HIPPS because it does not require any other fuels for normal operation. A fluidized bed, air blown pyrolyzer converts coal into fuel gas and char. The char is fired in a high temperature advanced furnace (HITAF) which heats both air for a gas turbine and steam for a steam turbine. The air is heated up to $760^{\circ} \mathrm{C}\left(1400^{\circ} \mathrm{F}\right)$ in the HITAF, and the tube banks for heating the air are constructed of alloy tubes. The fuel gas from the pyrolyzer goes to a topping combustor where it is used to raise the air entering the gas turbine to $1288^{\circ} \mathrm{C}\left(2350^{\circ} \mathrm{F}\right)$. In addition to the HITAF, steam duty is achieved with a heat recovery steam generator (HRSG) in the gas turbine exhaust stream and economizers in the HITAF flue gas exhaust stream. 


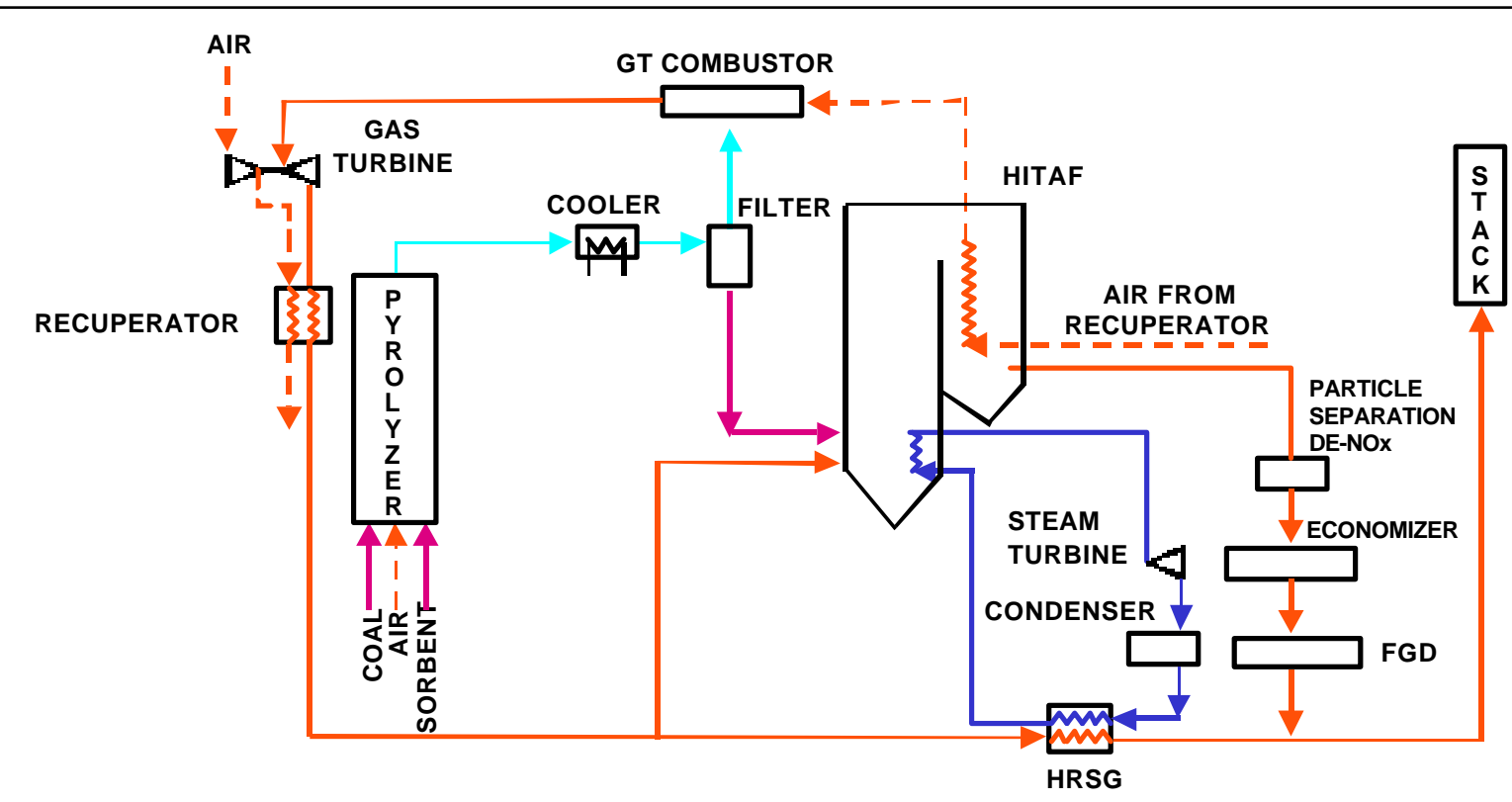

Figure 1 All Coal Fired HIPPS

An alternative HIPPS cycle is shown in Figure 2. This arrangement uses a ceramic air heater to heat the air to temperatures above what can be achieved with alloy tubes. This arrangement is referred to as the 35 percent natural gas HIPPS, and a schematic is shown in Figure 2. A pyrolyzer is used as in the base case HIPPS, but the fuel gas generated is fired upstream of the ceramic air heater instead of in the topping combustor. Gas turbine air is heated to $760^{\circ} \mathrm{C}\left(1400^{\circ} \mathrm{F}\right)$ in alloy tubes the same as in the All Coal HIPPS. This air then goes to the ceramic air heater where it is heated further before going to the topping combustor. The temperature of the air leaving the ceramic air heater will depend on technological developments in that component. An air exit temperature of $982^{\circ} \mathrm{C}\left(1800^{\circ} \mathrm{F}\right)$ will result in 35 percent of the heat input from natural gas.

A simplified version of the HIPPS arrangement can be applied to existing boilers. Figure 3 outlines the potential application of the HIPPS technology for repowering existing pulverized coal fired plants. In the repowering application, the gas turbine exhaust stream provides the oxidant for co-fired combustion of char and coal. The existing boiler and steam turbine infrastructure remain intact. The pyrolyzer, ceramic barrier filter, gas turbine, and gas turbine combustor are integrated with the existing boiler to improve overall plant efficiency and increase generating capacity. 


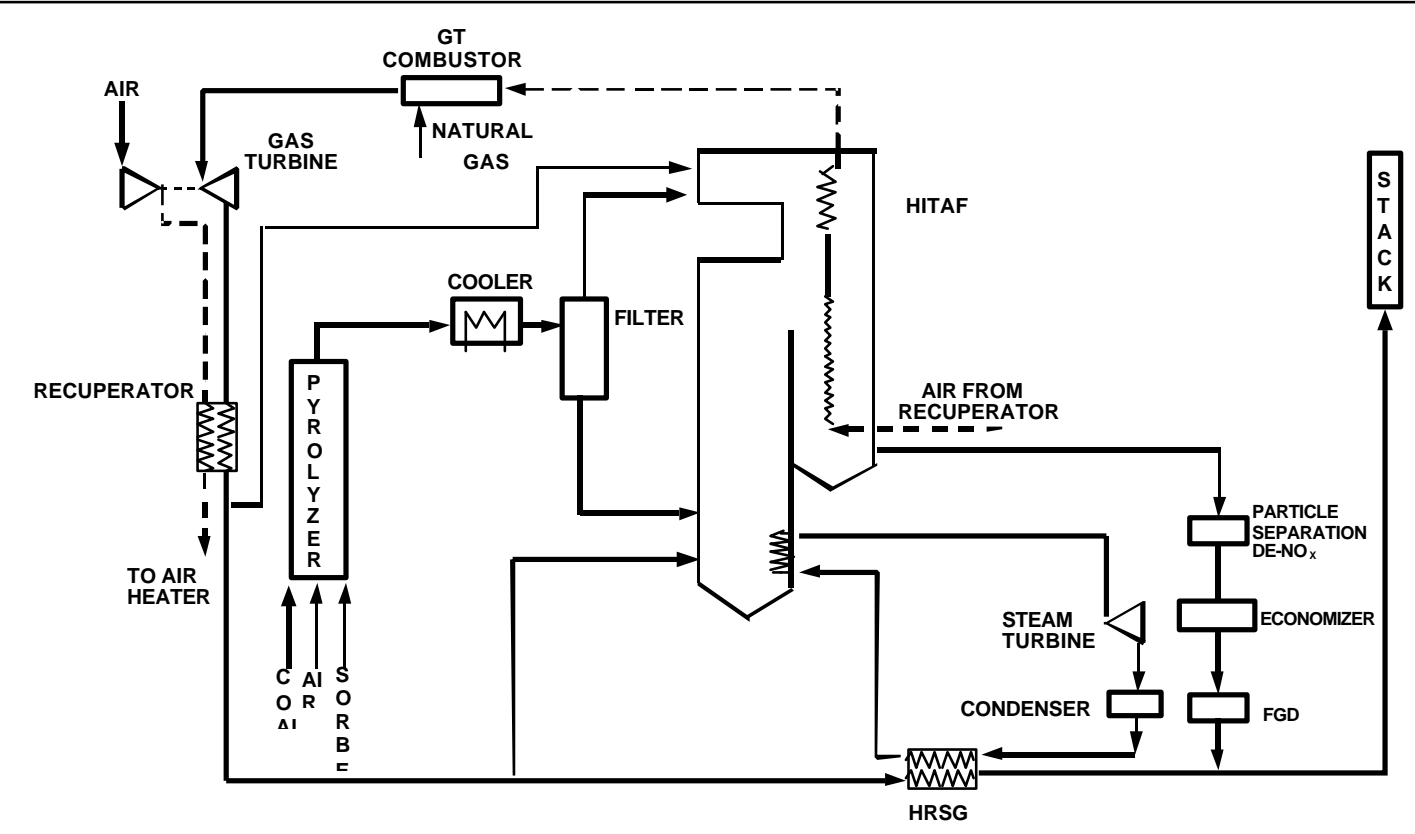

Figure 2 35-Percent Natural Gas

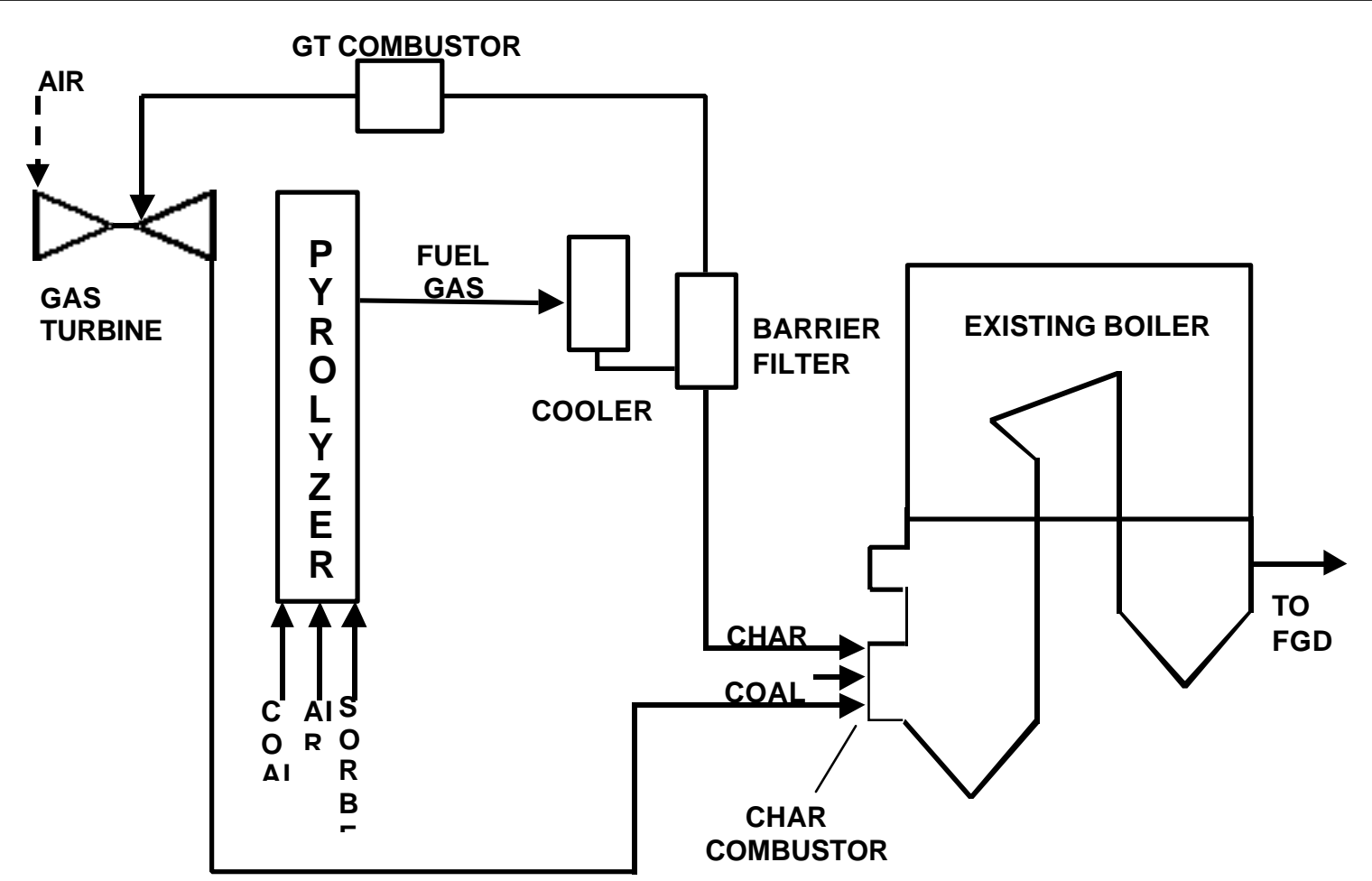

Figure 3 Simplified HIPPS Repowering Process Flow Diagram 


\section{TECHNICAL PROGRESS}

\section{Task 1 - Project Planning and Management}

Work is progressing according to the project plan.

\section{Task 2 - Engineering Research and Development}

No engineering $R \& D$ work was performed during this quarter.

\section{Task 3 - Subsystem Test Unit Design}

\section{Subtask - 3.1 Livingston Pilot Plant Design}

In fiscal year 2000, HIPPS pyrolyzer testing at FWDC's PFB Pilot Plant Facility in Livingston, NJ, is scheduled to take place. The bubbling bed pyrolyzer arrangement previously tested is to be retrofitted to operate as a circulating fluidized bed. The purpose of the test program is to demonstrate stable hydrodynamic performance and steady fuel gas composition. The circulating bed pyrolyzer is easier to scale up to commercial sized applications than the bubbling bed system, and, as such, has broader market potential.

In the current configuration of the pyrolyzer pilot plant, there is no syngas cooler installed between the pyrolyzer and syngas cleaning system. During the past tests, the syngas cleaning was cleaned by ceramic filters operated at the hot process temperature condition. However, one concern of hot gas cleaning systems utilized in HIPPS technologies is that some contaminants within the gas may pass through the particulate filter in the vapor form and cause corrosion and deposition problems in the downstream gas turbine. For coals, sodium and potassium are the principal elements causing concern. For petroleum coal, vanadium is the issue. For the HIPPS process, as the fuel is gasified in the pyrolyzer, the trace elements in the fuel are released and vaporized into the syngas. The only reliable and proven method today to capture these elements is to cool the gases enough to condense them onto ash particles and remove them via a particulate filter system. As a result, it was decided during this quarter that a syngas cooler will be designed and implemented for the future tests. The syngas cooler will be designed to cool the syngas down to $650{ }^{\circ} \mathrm{F}$ with the saturated steam from an existing steam boiler. Metallic filters will also be used for the syngas cleaning at the low temperature conditions. Due to this alternation of the CFB pyrolyzer configuration, the CFB pyrolyzer tests will be conducted in two separate series. The first series of tests will be performed under the original configuration without the syngas cooler as shown in Figure 4. The second series of tests will be performed under the new configuration with the syngas cooler and metallic filters as shown in Figure 5. The first series of tests is aimed to study the CFB pyrolyzer operation and performance itself. The second series of test is aimed to study the performance of the CFB pyrolyzer and syngas filtration system.

During this report period, one area of the existing CFB pyrolyzer design reported in the last quarter has been reviewed and modified. In the last design, a J-valve was proposed to be the pressure seal device between the pyrolyzer and solids recirculation loop, as shown in Figure 6. After reviewing the J-valve operation and construction, it was decided that a simple angled solids return leg will be designed and implemented in the 
future tests. The CFB pyrolyzer configured with an angled return leg is shown in Figure 7. FW has very successful experience with this simplified pressure seal device in the biomass gasification applications. Not like J-valve, this angled solids-return leg does not require any fluidization by the injection of either nitrogen or steam at the bottom. As a result, the product syngas is not diluted by this additional nitrogen/steam injection. Without any fluidization or aeration, the pyrolyzer operation will be simple. The operational cost also is reduced by the reduction of the nitrogen/steam cost. The angled solids-return leg is easy to configure and construct.

\section{Subtask - 3.2 Char Combustion System Test Design}

No design work was performed during this quarter.

\section{Task 4 - Subsystem Test Unit Construction}

\section{Subtask - 4.1 Livingston Pilot Plant Construction}

The demolition work of the existing bubbling-bed pyrolyzer is complete. The procurement work of the new addition to the CFB pyrolyzer has started in this quarter. Some preliminary construction work of the CFB pyrolyzer has been also started. The overall construction and testing schedule for the CFB pyrolyzer test is shown in Figure 8. Due to new changes to the test program, the original planned test schedule has been delayed by approximately three months. As shown in Figure 8, HIPPS testing on the circulating fluidized bed pyrolyzer can begin as early as February 2001.

\section{Subtask - 4.2 Char Combustion System Construction}

In our previous burner tests at our Combustion and Environmental Test Facility (CETF) in Dansville, NY, an indirect feed system was employed to deliver char to the burner in the arch-fired configuration. This system did not perform as originally specified by the vendor, and the fuel flow to the burner was unstable. The modifications to the existing indirect feed system are needed to improve both system performance and accuracy. The modification and construction work of the new feed system is complete in the last quarter. During this quarter, the indirect feed system was successfully commissioned and tested.

\section{Task 5 - Subsystem Test Unit Testing}

No experimental testing was performed during this quarter 


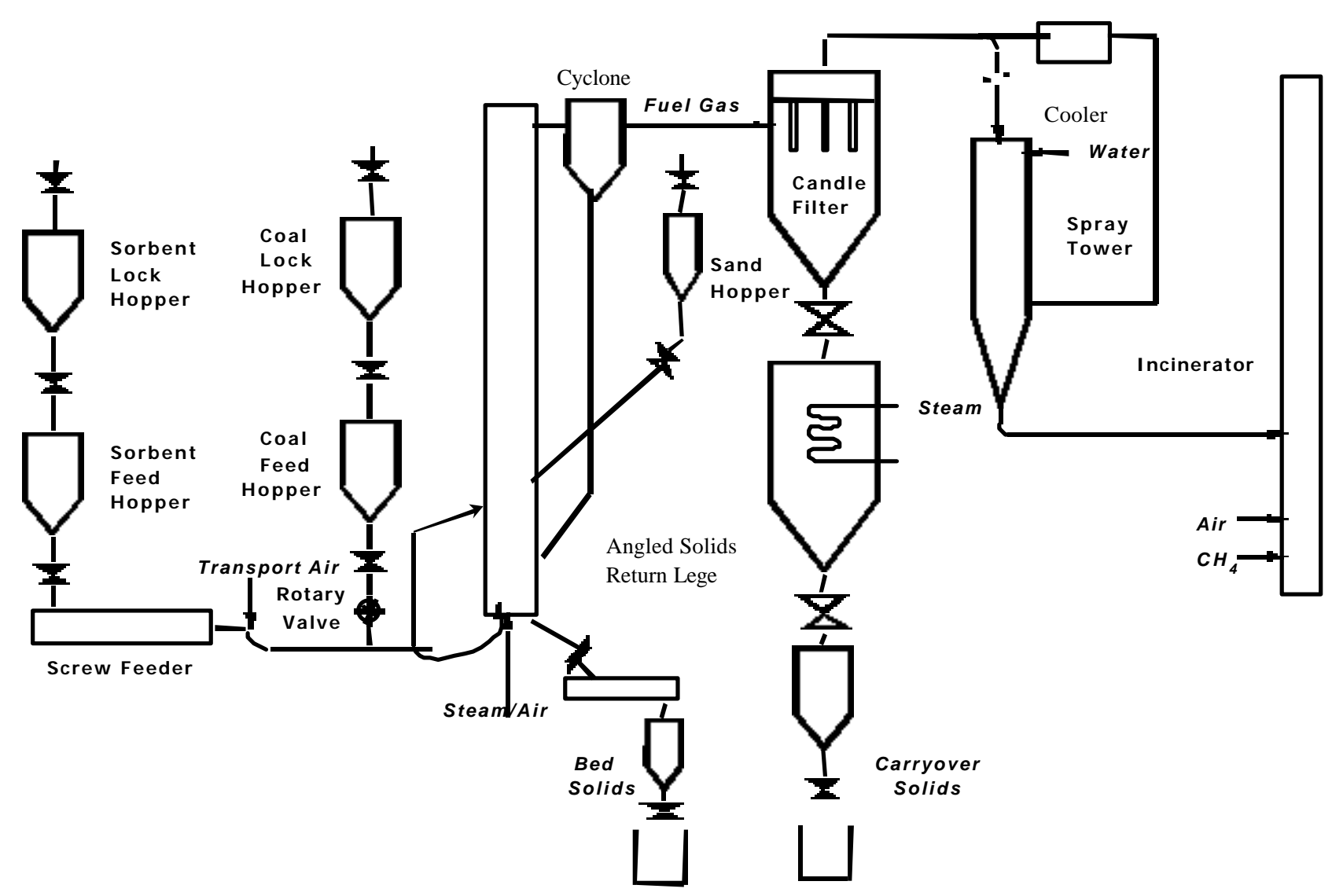

Figure 4 CFB Pyrolyzer System Flow Schematic For the Test Series I 


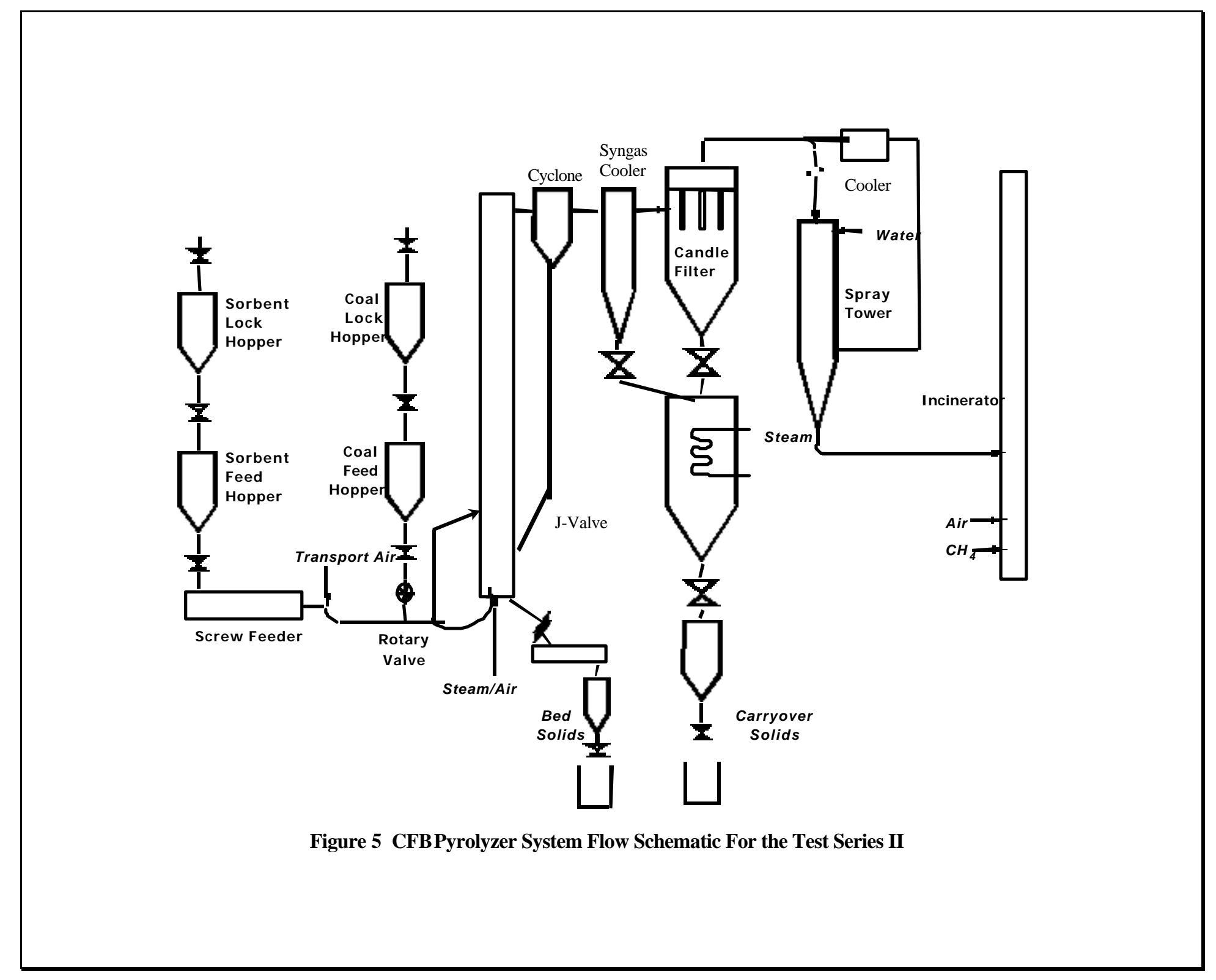




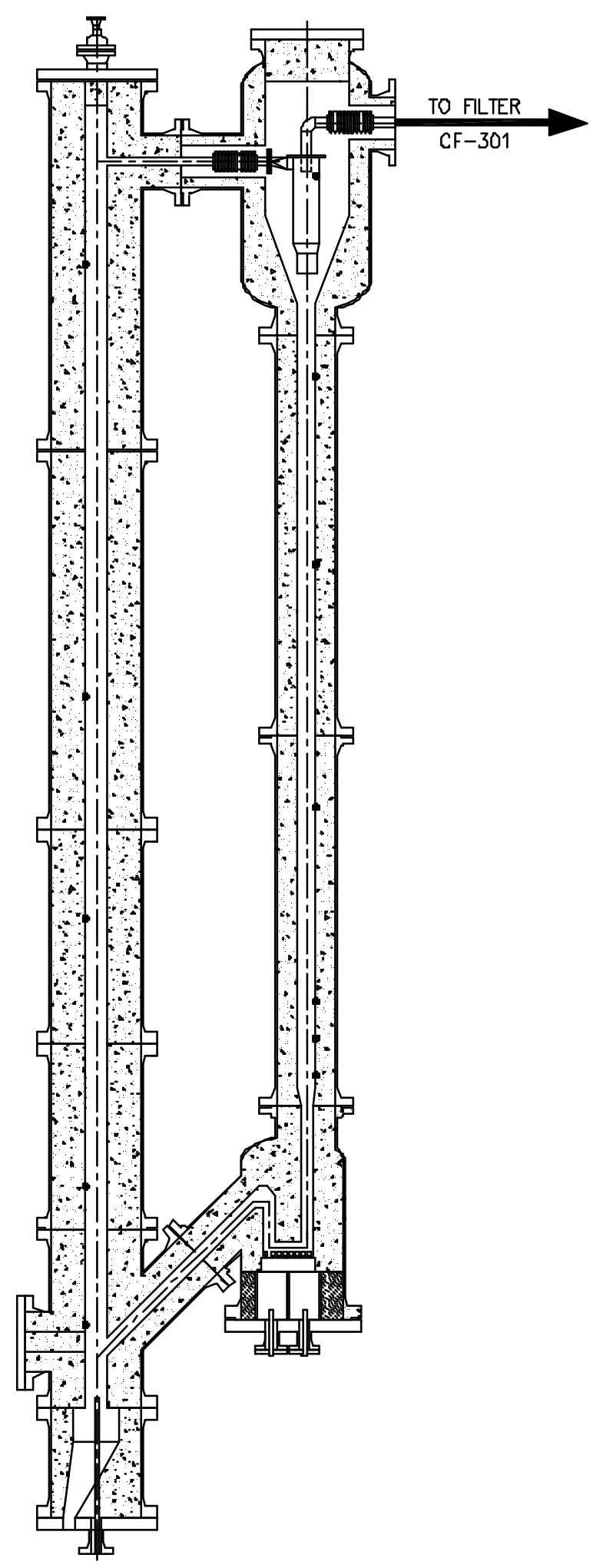

Figure 6 CFB Pyrolyzer with A J-Valve as the Pressure Seal Device 


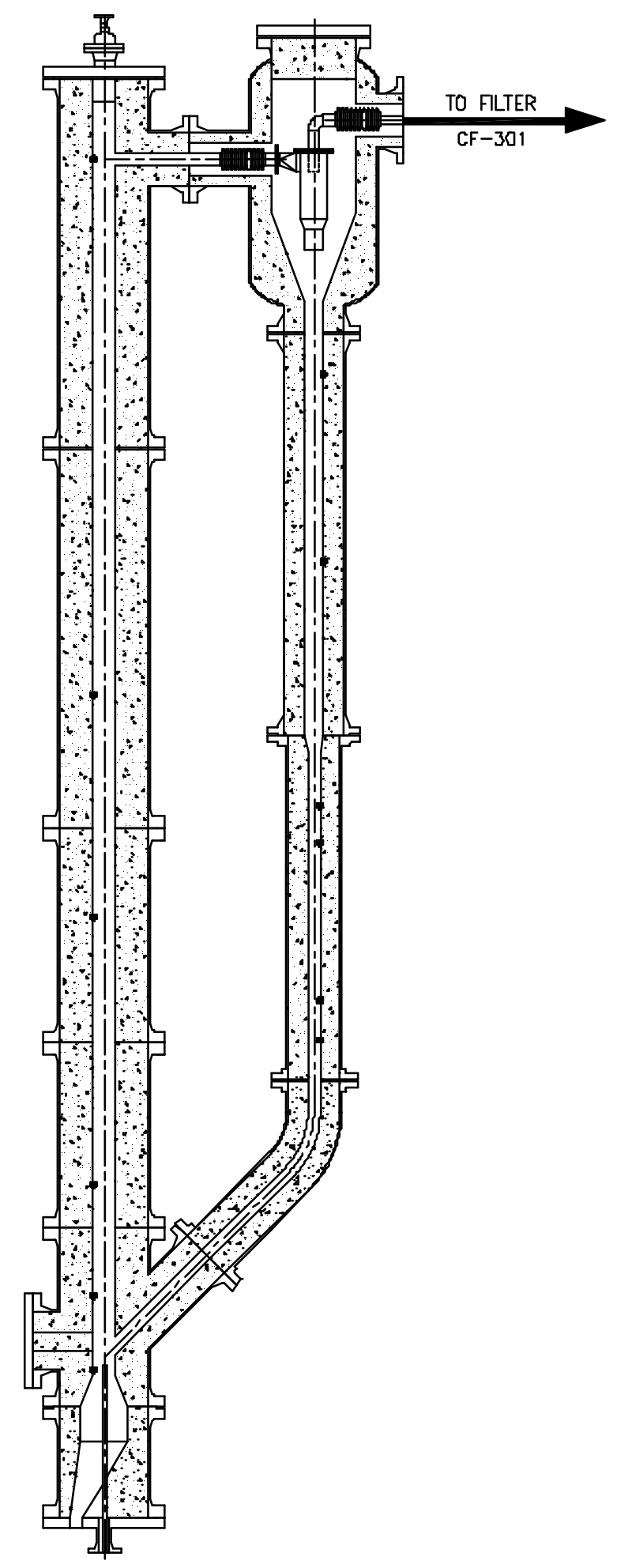

Figure 7 CFB Pyrolyzer with a Angled Solids-Return Leg as the Pressure Seal Device 


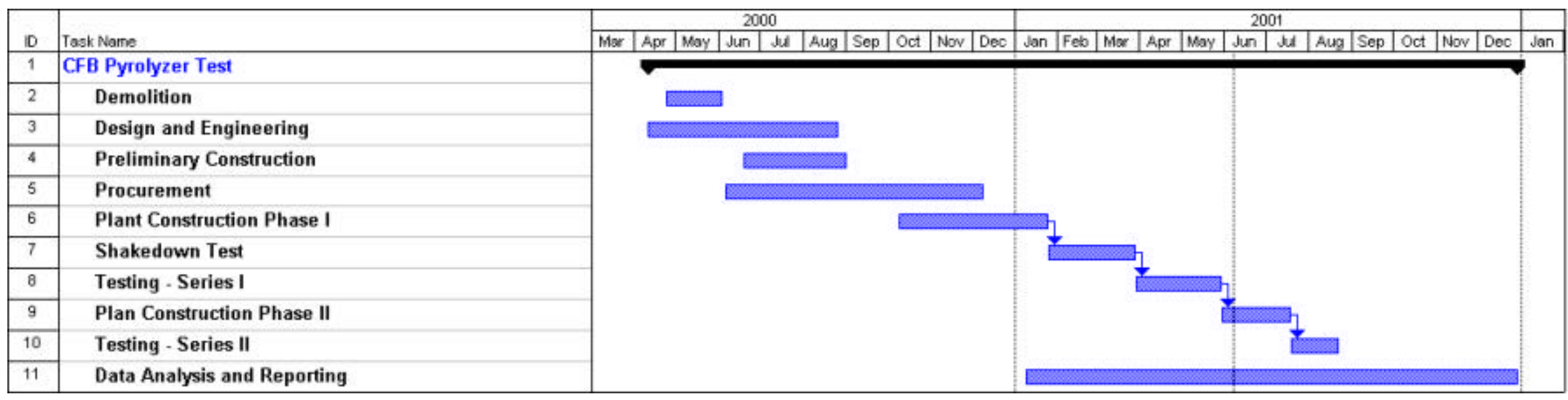

Figure 8 Overall CFB Pyrolyzer System Construction and Testing Schedule 